\title{
RUBUHA (RUMAH BURUNG HANTU) SAHABAT PETANI DESA TONDOMULYO
}

\author{
Ernawati Budi Astuti ${ }^{1}$, Cania Ferennita ${ }^{2 *}$, Ulfah Kholishotul Muna Mas'adah ${ }^{1}$, Fadia \\ Khairani $^{3}$, Sindi Desi Minanti ${ }^{3}$ \\ ${ }^{1}$ Program Studi Akuntansi, Fakultas Ekonomi, Universitas Wahid Hasyim \\ Jl. Menoreh Tangah X/22, Sampangan, Semarang 50236 \\ ${ }^{2}$ Program Studi Manajemen, Fakultas Ekonomi, Universitas Wahid Hasyim \\ Jl. Menoreh Tangah X/22, Sampangan, Semarang 50236 \\ ${ }^{3}$ Jurusan Agribisnis, Fakultas Pertanian, Universitas Wahid Hasyim \\ Jl. Menoreh Tangah X/22, Sampangan, Semarang 50236 \\ *Email: caniaferennita@gmail.com
}

\begin{abstract}
Abstrak
Kegiatan pengabdian masyarakat ini bertujuan untuk membantu masyarakat Desa Tondomulyo dalam mengatasi permasalahan hama tikus yang sedang dihadapi. Desa Tondomulyo terletak di Kecamatan Jakenan, Kabupaten Pati. Wilayahnya termasuk daerah dataran rendah, sehingga sebagian besar masyarakatnya bermata pencaharian di sektor pertanian yaitu petani padi. Dalam bercocok tanam para petani mengalami suatu permasalahan ancaman hama tikus. Desa Tondomulyo memiliki lahan pertanian yang luas dan hasil panennya kisaran 7-8 ton/ha. Namun, kerugian dari adanya hama tikus sangat meresahkan. Dalam sekali panen kerugiannya kisaran Rp. 1.036.000/ha, itu adalah 40\% dari hasil panen. Untuk mengatasi permasalahan tersebut tim pengabdi memberikan sosialisasi dan pelatihan online pembuatan RUBUHA (Rumah Burung Hantu). Pembuatan RUBUHA merupakan alternatif pengendali hama tikus yang ramah lingkungan pada lahan pertanian. Target sasaran program ini adalah anggota kelompok tani "Tani Jaya” Desa Tondomulyo. Tujuan yang ingin dicapai adalah (1) membuat modul dan video tutorial pembuatan RUBUHA sebagai media pelatihan pada kelompok tani, (2) memberikan sosialisasi dan pelatihan online pembuatan RUBUHA, (3) mengetahui manfaat program pengabdian masyarakat bagi kelompok tani Desa Tondomulyo. Metode yang digunakan dalam pelaksanaan kegiatan ini adalah teknik penyuluhan, teknik pelatihan dan pendampingan iptek.
\end{abstract}

Kata Kunci: Hama Tikus, Petani, dan Rumah Burung Hantu.

\section{PENDAHULUAN}

Indonesia merupakan negara agraris, hal ini dikarenakan sebagian besar penduduknya bermata pencaharian dibidang pertanian. Salah satu jenis pembangunan yang masih diupayakan di Indonesia adalah pertanian (Dai, 2019). Sektor pertanian menjadi salah satu sektor yang masih diandalkan di negara Indonesia, karena sektor pertanian mampu memberikan pemulihan pada saat terjadi krisis ekonomi (Pusparini \& Suratha, 2018). Peningkatkan produksi pertanian, dapat dilakukan secara bertahap dan berkelanjutan. Salah satu pertanian yang sering kita temui di Indonesia adalah Padi. Seperti halnya masyarakat di Desa Tondomulyo, wilayahnya termasuk dalam kategori dataran rendah, yang mayoritas masyarakatnya sebagian besar bercocok tanam sebagai petani, khususnya petani padi. Desa Tondomulyo merupakan salah satu desa di Kecamatan Jakenan, Kabupaten Pati, Jawa Tengah. Desa ini memiliki 4 pedukuhan, yaitu pedukuhan Tanianyar, Pencil, Sampang, dan Kedungbanteng.

Letak lokasi mitra pengabdian masyarakat ini sendiri berada di pedukuhan Tanianyar tepatnya RT/RW 06/04. Masyarakat sasaran pelaksanaan program ini adalah kelompok tani "Tani Jaya" Desa Tondomulyo. Jumlah penduduk di Desa Tondomulyo memiliki kecenderungan meningkat tiap tahunnya. Berdasarkan data BPS Desa Tondomulyo 2019 tercatat sebesar 2.080 jiwa, yang terdiri 1.000 jiwa penduduk laki-laki dan 1.080 jiwa penduduk perempuan. Dan memiliki luas wilayah mencapai $251.490 \mathrm{Km}^{2}$. Sebagian besar wilayahnya lebih dominan pada lahan pertanian dari pada pemukiman penduduk.

Mayoritas penduduk Desa Tondomulyo menggantungkan hidupnya pada alam sebagai petani padi. Daerahnya sangat cocok untuk dijadikan lahan pertanian dengan ketersediaan lahan yang masih sangat luas. Didukung juga letak geografis desa tersebut berada dipinggiran sungai Juwana 
yang biasanya digunakan untuk perairan sawah. Data rinci tentang Desa Tondomulyo terdapat pada tabel 1.

Table 1. Data Pekerjaan Desa Tondomulyo

\begin{tabular}{|c|c|c|}
\hline Pekerjaan & Jumlah & Persentase \\
\hline $\begin{array}{l}\text { Petani } \\
\text { Buruh pabrik } \\
\text { Buruh tani/buruh nelayan } \\
\text { Nelayan } \\
\text { Wiraswasta/pedagang } \\
\text { Pegawai swasta } \\
\text { PNS } \\
\text { TNI Lain-lain }\end{array}$ & $\begin{array}{c}730 \text { orang } \\
169 \text { orang } \\
120 \text { orang } \\
25 \text { orang } \\
13 \text { orang } \\
8 \text { orang } \\
6 \text { orang } \\
4 \text { orang } \\
2 \\
\text { orang }\end{array}$ & $\begin{array}{c}67,7 \% \\
15,7 \% \\
11,2 \% \\
2,4 \% \\
1,3 \% \\
0,7 \% \\
0,5 \% \\
0,3 \% \\
0,2 \%\end{array}$ \\
\hline Jumlah & 1077 orang & $100 \%$ \\
\hline
\end{tabular}

Para petani di Desa Tondomulyo mendapat ancaman gagal panen yaitu adanya hama tikus. Tikus sawah (Rattur Argentiventer) merupakan hama utama pada tanaman padi. Hewan ini menimbulkan kerusakan yang cukup parah mulai dari fase persemaian, fase generativ, sampai fave penyimpanan digudang penyimpanan produk pertanian. Kerusakan ini mengakibatkan berkurangnya bibit produksi serta kerusakan akibat kontaminasi (Bari, 2017). Menurut Bapak Sutrisno sebagai ketua kelompok tani Tani Jaya di Desa Tondomulyo rata-rata hasil panen padi bisa mencapai 7-8 ton/hektar. Namun, kerugian yang dialami kisaran Rp. 1.036.000/ha, itu adalah $40 \%$ dari hasil panen. Tentunya hal ini sangat meresahkan para petani di Desa Tondomulyo. Kerugian yang disebabkan oleh hama tikus bervariasi, tergantung populasi tikus yang ada dilahan persawahan. Kebanyakan kerugian yang dialami para petani adalah karena tikus merusak padi hingga rata tanah hanya dalam waktu semalam (Pusparini \& Surathna, 2018). Hama tikus menyerang padi pada malam hari, dan berkembang biak dengan cara membuat lobang di bawah tanah, hal ini menyebabkan populasinya semakin banyak karena hama tikus memiliki sifat adaptasi yang sangat tinggi (Sukmawati, dkk, 2017).

Bapak Sutrisno selaku ketua kelompok tani Tani Jaya mengungkapkan bahwa kelompok tani Desa Tondomulyo telah melakukan berbagai upaya pengendalian untuk mengusir hama tikus. Namun, semua teknik yang sudah dilakukan belum membuahkan hasil yang maksimal. Serangan tikus cenderung meningkat pada setiap tahunnya. Teknik pengendalian yang sudah dilakukan petani Desa Tondomulyo antara lain teknik gropyokan. Teknik ini mengakibatkan dampak negatif yaitu rusaknya bentuk fisik tanah dan tanaman padi karena terinjak para petani saat mengejar dan membunuh tikus. Teknik kedua yaitu dengan memasang jebakan tikus atau rat traps. Teknik ini biasanya diterapkan dirumah tetapi mereka juga menerapkannya disawah.

Hal tersebut juga kurang efektif karena pada lahan terbuka serta membutuhkan alat dalam kapasitas lebih besar. Teknik ketiga yaitu dengan menggunakan racun tikus yaitu redontisida (umpan racun lambung) dan fumigan (emposan berupa zat belerang). Akibatnya dari pemanfaatan teknik redontisida sendiri dapat mencemari hasil pertanian, membunuh musuh alami, dan mempengaruhi kesehatan manusia bila tidak berhati-hati dalam pemakaiannya. Sedangkan teknik fumigan akan mencemari tanah dan asapnya mudah terhirup petani sehingga akan menggangu kesehatan. Teknik terakhir yaitu melakukan pemagaran lahan menggunakan plastik mulsa yang bertujuan untuk mencegah agar tikus tidak masuk area lahan pertanian. Pemasangan pagar tersebut dilakukan sejak dini sebelum masa berbuah, tetapi memerlukan biaya yang banyak.

Salah satu predator alami yang dapat mengurangi jumlah hama tikus adalah burung hantu. Burung hantu berdampak positif untuk mengurangi jumlah populasi hama tikus karena ramah lingkungan, efisiensi waktu kerja petani dan tidak mengeluarkan biaya mahal (Sipayung, dkk, 2018). Burung hantu biasanya memangsa hewan-hewan kecil seperti tikus, kodok, kelinci, serangga dan lain-lain (Supriyadi \& Yanuartono, 2019). Burung hantu memiliki kemampuan yang 
baik dalam menangkap mangsanya, mempunyai penghihatan dan pendengaran yang tajam, paruh dan cakar yang kuat, serta kemampuan terbang yang cepat (Sukmawati, dkk, 2017).

Burung hantu jenis Tyto alba menjadi pilihan sebagai pengendali hama tikus yang ramah lingkungan. Tyto alba merupakan jenis burung pemangsa yang mempunyai peran penting didalam lingkungan lahan pertanian sebagai top predator atau pemangsa puncak dalam rantai makanan ekosistem sawah (Budhisurya, 2015). Warna putih mencerminkan ciri dari burung Tyto alba. Setiawan (2004) menyatakan Tyto alba mempunyai karakteristik kepala yang besar dan bulat, sorot mata yang tajam, bentuk muka yang mirip seperti hati yang mendominasi warna putih dan sedikit kecoklatan, warna sayap kelabu, paruh dan kuku kaki yang tajam, serta mempunyai daya cengkraman yang kuat yang digunakan untuk memburu mangsanya.

Pada umumnya burung hantu beraktivitas dan berburu pada malam hari mulai dari terbenamnya matahari dan siang harinya digunakan untuk tidur (Hadi, 2008). Tyto alba tidak suka memangsa makanan yang berbau busuk, seperti cecurut, bangkai tikus, dll. Dalam sehari burung hantu besar dapat memangsa tikus hidup 2-3 ekor, tergantung ukuran dari sitikus. Untuk tikus yang relatif kecil burung hantu memakannya dengan cara ditelan secara langsung. Dan untuk ukuran tikus yang besar burung hantu membaginya terlebih dahulu menjadi beberapa bagian sebelum ditelan (Setiawan, 2004). Penggunaan burung hantu sebagai predator alami dirasa cukup efektif dalam pengendali hama tikus. Selain yang ramah lingkungan, cara ini juga dapat menjaga ekosistem persawahan yang mulai rusak. Di Desa Tondomulyo sendiri banyak dijumpai burung hantu (Tyto alba) liar, yang biasanya bertempat tinggal di pepohonan sekitar lahan persawahan. Tetapi akhir-akhir ini banyak pepohonan yang ditebang sehingga burung hantu banyak kehilangan tempat tinggalnya serta banyak diburu yang menyebabkan berkurangnya jumlah populasi Tyto alba di Desa Tondomulyo.

Metode pemanfaatan burung hantu ini dirasa cukup efektif sehingga perlu adanya pembuatan rumah burung hantu (RUBUHA) untuk menjaga populasinya. Penerapan RUBUHA (Rumah Burung Hantu) bertujuan untuk dijadikan sebagai tempat transit burung hantu liar. Dimana burung hantu merupakan predator alami yang ramah lingkungan dan tidak menimbulkan residu yang bahaya bagi makhluk hidup lainnya. Teknologi pemanfaatannya sangat mudah diterapkan. Teknik pengendalian dengan menggunakan predator alami burung hantu dalam jangka panjang akan menunjukkan efisiensinya, karena burung hantu akan berkembang biak dan mengurangi biaya pengendalian (Sipayung, dkk, 2018). Dengan adanya RUBUHA (Rumah Burung Hantu) diharapkan burung hantu dapat bertempat tinggal dan berkembang biak sehingga mengurangi hama tikus di area persawahan di Desa Tondomulyo.

\section{METODE}

Metode pelaksanaan pengabdian masyarakat kepada kelompok Tani Jaya di Desa Tondomulyo, ditunjukkan pada Gambar 1.

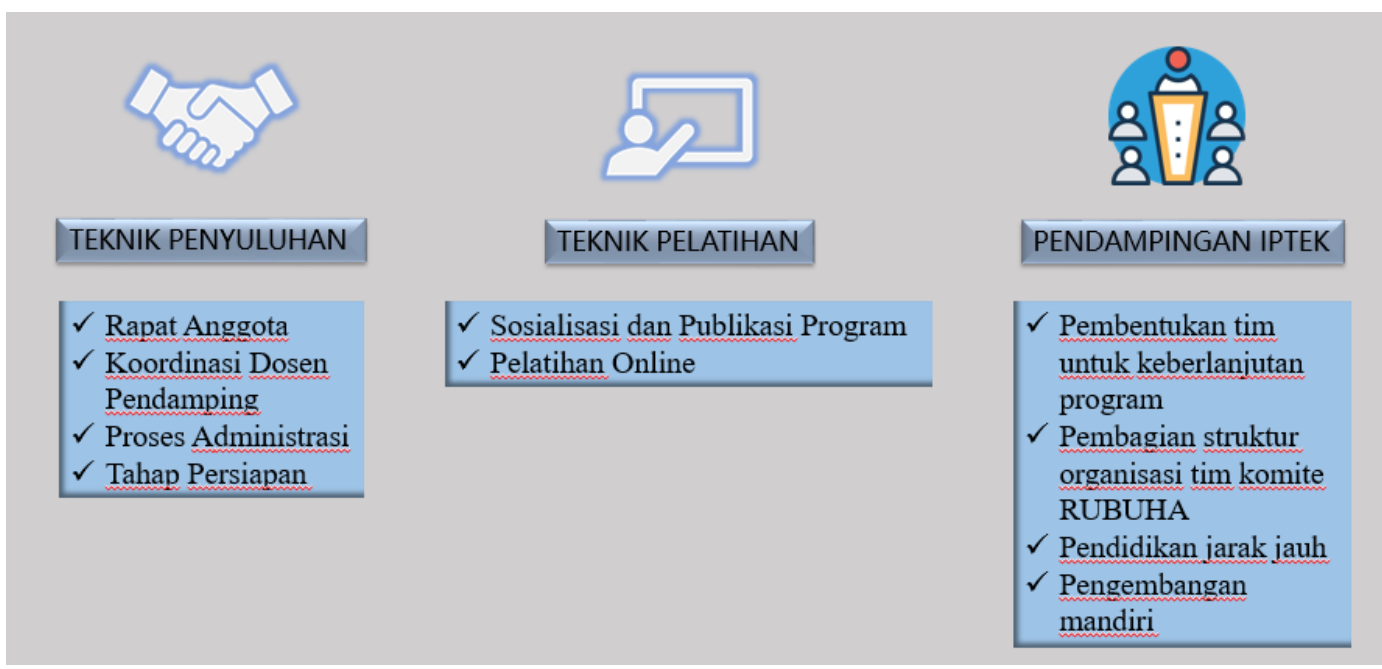

Gambar 1. Rencana Kegiatan Kepada Masyarakat Mitra 
Berikut ini merupakan penjabaran metode pelaksanaan program pengabdian masyarakat sesuai dengan Gambar 1.

a. Teknik Penyuluhan

Di dalam teknik ini, kegiatan yang akan dilakukan ada beberapa tahapan yaitu:

1. Rapat anggota

Tahap ini bertujuan untuk menyerahkan pendapat anggota dengan ketua, strategi yang akan diambil, dan pembagian tim kerja.

2. Koordinasi Dosen Pendamping

Tahap ini bertujuan untuk meyerahkan hasil rapat anggota kepada dosen pendamping agar mendapatkan masukan terhadap langkah strategis yang akan diambil selama pelaksanaan dan keberlanjutan program.

3. Proses Administrasi

Tahapan ini untuk melakukan proses perizinan dan koordinasi secara daring dengan salah satu warga Desa Tondomulyo yang menjadi mitra yaitu Bapak Sutrisno selaku ketua kelompok tani "Tani Jaya."

4. Tahap Persiapan

Persiapan yang dilakukan yaitu dengan membuat modul atau buku pedoman aplikasi produk serta video tutorial pembuatan produk RUBUHA (Rumah Burung Hantu) yang akan digunakan saat pelaksanaan kegiatan. Selain itu peralatan atau media yang digunakan dalam pelaksanaan kegiatan juga dipersiapkan pada tahap ini melalui aplikasi teleconference yaitu WhatsApp.

b. Teknik Pelatihan

Di dalam teknik ini kegiatan yang dilakukan ada dua tahapan, yaitu :

1. Sosialisasi dan Publikasi

Program Sosialisasi dan publikasi program bertujuan untuk memberikan edukasi dan pengenalan kepada kelompok tani tentang apa itu RUBUHA (Rumah Burung Hantu), serta seberapa penting pemanfaatannya sebagai alternatif pengendali hama tikus yang ramah lingkungan pada lahan pertanian Desa Tondomulyo.

2. Pelatihan Online

Pelatihan pembuatan produk RUBUHA (Rumah Burung Hantu) dilakukan secara daring dengan memberikan modul serta video tutorial pembuatan produk yang harapannya masyarakat lebih mudah dalam memahaminya.

c. Pendampingan IPTEK

Di dalam teknik ini kegiatan yang dilakukan ada dua tahapan, yaitu:

1. Pembentukan tim untuk keberlanjutan program

Tim keberlanjutan program ini dinamakan tim komite RUBUHA (Rumah Burung Hantu) yang bertujuan untuk menjaga keberlanjutan program.

2. Pembagian struktur organisasi tim komite RUBUHA

Tujuannya supaya dalam melaksanakan keberlanjutan program kepengurusan mengetahui dan dapat melakukan job desk masing-masing.

3. Pendidikan jarak jauh

Bertujuan untuk mengarahkan, memantau, dan memberi masukan tindakan tim komite RUBUHA (Rumah Burung Hantu), serta memberikan informasi dengan cara mengadakan pertemuan daring secara berkala. Diadakannya pendidikan jarak jauh harapannya kelompok tani Desa Tondomulyo turut serta mempelajari dan menerapkan pembuatan RUBUHA (Rumah Burung Hantu) pada lahan pertanian Desa Tondomulyo sehingga permasalahan berupa ancaman hama tikus dapat teratasi.

4. Pengembangan mandiri

Tujuannya yaitu memberikan kebebasan kepada tim komite RUBUHA (Rumah Burung Hantu) untuk bereksplorasi melanjutkan program dan kegiatan secara mandiri.

\section{HASIL DAN PEMBAHASAN}

Kegiatan pengabdian masyarakat ini dilakukan berdasarkan Program Kreativitas Mahasiswa (PKM) berjudul RUBUHA (Rumah Burung Hantu) Sahabat Petani Desa Tondomulyo. Kegiatan ini mempunyai tujuan untuk membantu memecahkan permasalahan hama tikus pada lahan pertanian 
Desa Tondomulyo supaya lebih baik dan menciptakan petani yang makmur. Pelaksanaan program dilakukan secara daring karena diadakan pada saat pandemi COVID 19. Hasil dan pembahasn dari pelaksanaan program pengabdian masyarakat ini adalah sebagai berikut :

1. Jasa berupa bentuk pengetahuan tentang manfaat dan cara penerapan RUBUHA (Rumah Burung Hantu) sebagai alternatif pengendali hama tikus yang ramah lingkungan pada lahan pertanian Desa Tondomulyo melalui sosialisasi dan publikasi program. Proses sosialisasi dilakukan secara daring

melalui yaitu video call WhatsApp grup. Kegiatan ini diikuti oleh perwakilan anggota kelompok tani karena tidak semua anggota kelompok tani dapat berkomunikasi secara daring melalui WhatsApp. Metode sosialisasi yang dilakukan menggunakan metode pendidikan orang dewasa (andragogi) yaitu ceramah dan diskusi. Tim pengabdi memberi edukasi dan pengenalan kepada kelompok tani tentang apa itu RUBUHA serta seberapa penting pemanfaatannya sebagai alternatif pengendali hama tikus yang ramah lingkungan pada lahan pertanian.

2. Produk berupa buku pedoman dan video animasi tutorial pembuatan RUBUHA (Rumah Burung Hantu) sebagai alat bantu pemahaman masyarakat terhadap program melalui pelatihan online. Pelaksanaan pelatihan dilakukan secara daring dengan cara diskusi melalui WhatsApp grup. Kegiatan dimulai dari pembukaan sampai diskusi Tanya jawab. Presentasi dilakukan dengan bantuan modul/buku pedoman yang sudah dibuat lalu menampilkan video animasi cara pembuatan RUBUHA, sampai diskusi tanya jawab.

3. Terbentuknya tim komite RUBUHA sebagai agen pendukung keberlanjutan program melalui pendampingan iptek. Pendampingan iptek yang dimaksud ini lebih fokus untuk program keberlanjutan. Tahapan yang dilakukan meliputi pembentukan tim keberlanjutan program, pembagian struktur organisasi tim komite RUBUHA, pendidikan jarak jauh, dan pengembangan mandiri dengan cara memberikan kebebasan kepada tim komite RUBUHA untuk bereksplor melanjutan program dan kegiatan. Kemudian juga diskusi membahas rencana melakukan kerjasama dengan berbagai pihak salah satunya Penyuluh Pertanian Lapangan (PPL). Tim pengabdi juga membagikan kuesioner online untuk melihat seberapa pemahaman kelompok tani terhadap semua kegiatan yang sudah berlangsung.

Kelompok tani Desa Tondomulyo memberikan respon yang sangat baik dan mendukung adanya program ini. Bapak Sutrisno selaku ketua kelompok tani Tani Jaya mengatakan bahwa setelah adanya program ini semoga dapat menjadikan manfaat serta barokah untuk masyarakat Desa Tondomulyo khususnya masyarakat yang bermata pencaharian sebagai petani. Selainitu, potensi keberlanjutan merupakan aspek terpenting dalam program pengabdian masyarakat. Keberlanjutan program ini didukung dengan terbentuknya tim komite RUBUHA beserta struktur organisasinya. Karena antusias dari mitra untuk mendukung program ini maka dibentuklah struktur organisasi yang terdiri dari ketua, wakil ketua dan juga divisi lainnya. Tim komite RUBUHA ini diketuai oleh ketua kelompok tani sendiri yaitu Bapak Sutrisno. Tim komite RUBUHA bertugas sebagai penyebar informasi kepada para petani yang lain mengenai pentingnya penerapan RUBUHA pada lahan pertanian mereka. Selain itu, tim inilah yang akan bertanggung jawab penuh untuk berupaya merealisasikan pendirian RUBUHA dengan mencari dana dari beberapa sumber, baik dari iuran para petani hingga mencari bantuan pertanian dari sumber yang lain. Diharapkan dengan terbentuknya struktur organisasi ini dapat menjaga keberlanjutan program. Keberlanjutan program ini juga mendukung beberapa aspek kehidupan yaitu :

1. Aspek Lingkungan

Kegiatan penerapan RUBUHA ini merupakan tindakan menjaga konservasi alam yaitu sebagai upaya untuk melestarikan dan mengembangkan burung hantu yang populasinya semakin menurun. Dalam jangka panjang akan semakin menunjukkan efektifitasnya, karena burung hantu akan berkembang biak dan akan mengurangi biaya pengendalian.

2. Aspek Ekonomi

Setelah warga mampu memahami akan pentinggnya penerapan RUBUHA dan merealisasikan program dengan baik, maka masalah ancaman hama tikus akan teratasi dan hasil panennya akan kembali normal. Dengan demikian dapat meningkatkan perekonomian masyarakat. Selain itu juga dapat melahirkan peluang komersial yaitu peluang usaha bagi masyarakat menjadi pengrajin atau penjual RUBUHA. 
3. Aspek Sosial

Dengan berhasilnya Desa Tondomulyo dalam program ini diharapkan dapat menginspirasi desa lain dalam memanfaatkan penerapan RUBUHA (Rumah Burung Hantu) sebagai alternatif pengandali hama tikus yang ramah lingkungan pada lahan pertanian.

\section{KESIMPULAN}

Terselenggaranya Program Pengabdian Masyarakat "RUBUHA (Rumah Burung Hantu) Sahabat Petani Desa Tondomulyo" merupakan salah satu upaya untuk mengatasi permasalahan yang sedang dihadapi Kelompok Tani Desa Tondomulyo yaitu adanya serangan hama tikus pada lahan pertanian. Program tersebut telah terlaksana secara daring melalui sosialisasi dan publikasi program serta pelatihan online yang lakukan dengan media teleconference WhatsApp grup. Selain itu, dengan menggunakan media pendukung yakni video animasi dan modul/buku pedoman yang sangat menginspirasi dan memudahkan kelompok tani dalam proses pemahaman. Dalam program ini juga telah dibentuk tim komite RUBUHA sebagai aset keberlanjutan program.

Semua kegiatan dapat dinilai sudah berjalan dengan baik, pasalnya semua kegiatan yang dilakukan sudah sesuai dengan timeline yang terjadwal. Meskipun kegiatan pengabdian masyarakat ini dijalankan pada masa pandemi COVID 19 yang tidak diperbolehkan adanya perkumpulan, akan tetapi dapat berjalan dengan lancer berkat dukungan dan respon yang sangat baik dari masyarakat dan kelompok tani Desa Tondomulyo.

\section{DAFTAR PUSTAKA}

Budhisurya, Eriandra dkk. 2015. Analisis Partisipasi Petani dalam Pemanfaatan Burung Hantu (Tyto Alba) di Desa Tlogoweru Kabupaten Demak. E-Jurnal Fakultas Pertanian Universitas Sebelas Maret. 1 (1): 450-463.

Hadi, M.-. (2012). Pola Aktivitas HarianPasangan Burung Serak Jawa (Tyto alba) di Sarang Kampus Psikologi Universitas Diponegoro Tembalang Semarang. Bioma : Berkala Ilmiah Biologi, 10(1), 23. https://doi.org/10.14710/bioma.10.1.23-29.

Hayati, K. (n.d.). (2020). Studi Etiologi Burung Hantu (Tyto alba) di Penangkaran Desa Tlogoweru Guntur Demak Jawa Tengah. Jurnal Ilmiah Konsevasi Hayati, 16(1).

Istiaji, B., Priyambodo, S., Sanmas, A. A., \& Rosidah, A. (2020). Efektifitas Kegiatan gropyokan Tikus Sawah (Rattus argentiventer) di Desa Bener, Kabupaten Klaten (Effectiveness of ricefield rat (Rattus argentiventer) activities in Bener Village, Klaten Regency). Jurnal Pusat Inovasi Masyarakat, 2(2), 163-168.

Putri, F. D., Churiyah, M., Prayogo, I., Harimurti, K., Malang, U. N., Malang, U. N., Sastra, F., Malang, U. N., \& Malang, K. (2018). Strategi Penekanan Populasi Tikus Dengan Rubuha ( Rumah Burung Hantu ) Di Persawahan Desa Plumpang Lamongan. 3(2), 74-79.

Rumardianan A, Atikah (2020, Juli-September). Sosialisasi Mengoperasikan Teknologi Informasi Kepada Ibu-ibu PKK Pangkalan Jati Baru Depok. Jurnal PKM: Pengabdian Masyarakat, 3 (3), 189-190.

Setiawan. 2004. Tyto Alba Sahabat Petani. Ngawi: Lembaga Gita Pertiwi.

Sipayung, E. R., Sitepu, S. F., \& Zahara, F. (2019). Evaluasi Serangan Tikus Sawah (Rattus argentiventer Robb \& Kloss) Setelah Pelepasan Burung Hantu (Tyto alba) di Kabupaten Deli Serdang. Jurnal Agroekoteknologi, 6(2), 345-355. 